\title{
Figures of Repetition in the Performance of the Italian Folktale
}

\author{
Fotini Egglezou \\ MEd. \& PhD. in Teaching Language Arts \\ E-mail: fegglezou@yahoo.gr \\ Thanassis Nakas \\ Professor of Linguistics, University of Athens \\ E-mail: anakas@primedu.uoa.gr
}

\section{Doi:10.5901/mjss.2014.v5n1p621}

\begin{abstract}
This paper concerns the examination of stylistic features of the Italian folktale, presented through the use of figures of speech in a continuous correlation to the whole aesthetic of the genre as realized by the 'law' of repetition. The study, based on the analysis of hundred fifty-six transcribed oral Italian folktales is influenced by the ethnographic approach, which focuses on the story-teller and the folktale's performance, the genre theory and the qualitative stylistic analysis. Emphasis is put on the figures that reveal the repetition of lexical and syntactic patterns of speech. Especially, usual and particular uses of the figure of epanadiplosis are presented, as the accumulative epanadiplosis, the gradable epanadiplosis, the emphatic epanadiplosis. Also, figures of main interest consist epanaphorá and its variances and the main sub-categories of epanastrophe as: (a) (synthetic)-generative, b) syntactic and c) cohesive epanastrophe. Last but not least, the figure of tautology is examined. The extended use of the above figures formates an artistic folktale grammar coupled with the analogous rhetorical dynamic.
\end{abstract}

Keywords: repetition, figures of speech, performance, Italian folktale

\section{Theoretical Ground}

The folktale-world provides scholars with the opportunity to examine several aspects of its distinct language and style as the use of figures of speech. Such a study on the Italian folktale may contribute to the extension of the knowledge on the narrative folk-form in Europe, because of its significant influence to the development of the ancient art of story-telling as one of the most powerful guardians both of diachronic and universal linguistic modes of expression and of sociocultural beliefs (Wilson 1983; Fettermann $1998: 60$ ).

Indeed, the Italian folktale provided with an important impetus the spread of the European folktale. Calvino (1956) talks about its interaction with the German and the French folktales, while Cecilia Gatto Trocchi (2003) assumes that various types of Italian folktales correspond to tales taken from cultures in the Mediterranean See or even from Romanie (p.12). Folklorists as the German Hugo Hepding and the British Richard Dawkins, point out the similarity of Greek and Italian folktales giving to the latters "a leading place" since the period of the Venetian occupation of Greek territories (Dawkins 1942; Meraklis 1999:21). The above geographical affinities of the Italian folktale affirm Lüthi's conviction that "the folktale is a world-encompassing (welthaltig) literary form..." (1982: 76). Simultaneously, the influence of the Italian folktale excites the interest in the verbal means through which it is subject to collective, uniform and universal laws of the narrative folk creation (Jacobson 1966:91), as the law of repetition that shapes the function, the performance, the structure, the style and the whole aesthetic of the folktale as a genre (Propp 1984:41-2).

Repetition is defined as the dominant recurrence of structural, thematic, phonological, stylistic and linguistic patterns within the oral literature (Gray 1971) and, especially, the folktale (Lüthi 1987:78). As a narrative mechanism, repetition implements diverse functions (structural, rhetorical, psychological, linguistic, stylistic) during the performance. For Axel Olrik (1992:44) the 'epic laws' of repetition emphasize the essential parts of the plot, while Propp (2012:176) stresses that the trembling, as a repetitive technique, empowers and intensifies actions and emotions of the heroes as well as of the story-teller and of its audience. Max Lüthi (1987:76) recognizes the psychological effects of repetition, as the feelings of relaxation and security generated both to the story-teller and to the audience. Thus, as a stylistic device, the reiteration of linguistic patterns, as words or phrases, is considered to guarantee the coherence of the narration 
(Berry 1991: xvii). For Finnegan (1992:164), the narration of the folktale is the verbal art which applies the principle of the repetition due to the use of various figures of speech.

The lattest remark is closely linked to the lingo-stylistic approach as well as to an interrelated, prominent approach of the new folkloristics that is genre theory. According to the latter, the cultural function of the folk genres is examined through their verbal expression, stylistic form and aesthetic results (Niedermüller 1976:299-300) due to the influence of the seminal work of Volosinov (1929/1986) and Bakhtin (1978/1986). Especially, the folktale is considered a particular form of speech communication "in use" with an "esthetic, expressive or stylistic dimension" (Hymes 1974:131, 133; BenAmos and Goldstein 1975). Under this perspective, the verbal performance of the folktale, situated in a certain cultural context, acts as a rhetorical connector between the performer, the text and the audience (Green 1997:726) and demonstrates the collaboration of social and linguistic features of the primitive narrative art. The linguistic choices of the performer, since they conduce to an artful, stylized and communicative use of the language, become the essential tool for the successful transmission of the genre and the successive construction (or transformation) of the common social life (Bauman and Briggs 1990:69). The figures of speech consist of important linguistic, expressive means for the achievement of the above communicative goals (Gläser 1986:45).

As it becomes obvious, the purpose of our research that is the study and presentation of the main figures of speech that feature the stylistic device of repetition in the Italian folktale falls into the prementioned theoretical background. It is worth noting that the research will not be limited only to the indicative detection of the figures. Also, an important area of interest will be the examination of their implication for the development of the rhetorical dynamic of the genre.

\section{Materials and Methods}

The genre theory and the ethnographic approach consist of the methodological context of the following research. The figures are examined as necessary symbolic linguistic structures (Chua 1986:615) through which is achieved the successsful transmission of the folktale to the audience as well as dominant patterns of style (style markers) following a "multilevel approach of style" (Leech and Short 1981/2007:28). The qualitative lingo-stylistic analysis is based on the taxonomy of (morpho)lexical and phrasal figures of repetition as proposed by Nakas (2005). The focus on lexical and grammatical categories is imposed by the occurrence of the figures in compound words or by the syntactic relation of the sentences where the figures are spotted. Also, the phonological description is not omitted where necessary (mixing categories). The primary data of the research is based on two collections of Italian folktales: a) Fiabe Lombarde (1986) [Lombardian Folktales] and b) Le più Belle Fiabe Popolari Italiane (2003) [The most Beautiful Italian Folktales] and consists of 156 folktales transcribed and translated from the original regional dialect to the Italian language.

\section{Figures of Repetition in the Italian folktale: Findings}

The study of our corpus pointed out the extended use of the following figures: a) accumulative, b) emphatic, c) gradable epanadiplosis, d) epanastrophe, e) epanaforá, f) epiforá and g) tautology.

\subsection{The figure of accumulative epanadiplosis (AE)}

The (AE) denotes an accumulative repetition of the heroes' actions (Nakas, 1996a). Its occurrence is classified to the following categories: i) (AE) of motion verbs which expresses either the manner of the motion, therefore its "physical modality" (Fialová 2011:8), as camminare (=to walk), andare (=to go), volare (=to fly), girare (=to turn), andare via (=to go away) $<1>$ or its "direction" (path verbs) (Kudrnáčová 2008) as calare (=to go down), abbassarsi (=to descend), scendere (=to get down), salire (=to a-scend, to go up) <2>. As regards the intonation of the prosodic, suprasegmental phonological characteristics of the figure, we discern a suspensive intonation, indicative of the continuity or the duration of the action: f.e. $\mathrm{GI}\left({ }^{2} \rightarrow\right)$ rano $\mid \mathrm{GI}\left({ }^{2} \rightarrow\right)$ rano $\mid \mathrm{GI}\left({ }^{2} \rightarrow\right)$ rano $(\ldots)$.

$<1>$ E così, poverini, girano girano girano, e si ritrovano dietro il palazzo [...], <2> Cala cala cala... dopo un bel po' il corbello toccò il fondo.

The repeated motion verbs occur, mainly, in the third person narrative form of singular or plural denoting the referential function of the language (Guiraud 1975:88-93) in various tenses as: historic/dramatic present that empowers the 
narration and perks up the past into the present, past continuous, present perfect, simple past and less often simple future $\langle 3-7\rangle$. In this way it is denoted the aspect of the verb, which indicates a progressive, perfective or imperfective action (Dardano \& Trifone 1995: 316-7).

$<3>$ Cammina, cammina, girò a lungo [...], <4> Man mano che gli veniva fame, si abbassava, si abbassava, $e$ allora lei capiva [...], $<5>\mathrm{E}$ ha camminato ancora avanti, ha camminato camminato, è arrivato in un posto [...], $\langle 6\rangle$ Camminarono e camminarono. [...] E continuarono a camminare; [...], <7> Scenderai e scenderai nel pozzo finchè toccherai terra.

Often, the reiterated motion verb is preannounced by a synonym or an etymologically related verb/verbal phrase to declare the cue stage of the locomotion $\langle 8\rangle$. The figure may occur in successive stages of the narration providing a "ritual" character of recurring motives and topics (Meraklis 1988:22) $\langle 9-10\rangle$, while it represents progressive activities in space and/or in time accumulated each one over the other <11-12>. Often, the (AE) of the motion verb may consist of an

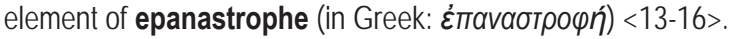

<8> Ripresero il cammino e dopo aver camminato e camminato, giunsero a Roma [...], <9> Cammina e cammina, incontrò un signore [...]Cammina ancora un poco, incontrò un altro signore [...] Allora tutta contenta cammina e cammina, ad un tratto vide un bel Castello [...], <10> Cammina cammina cammina, venne notte. [...] II principe parti e, cammina cammina cammina, finalmente trovò il posto [...] II principe si rimise a camminare e, cammina cammina cammina, verso sera arrivò [...], $<11>$ Caiusse traversò monti e valli e cammina cammina (2 times) arrivò ad un porto $[\ldots]<12>E$ adesso seguiamo Ariodante, che va e va e va $(3$ times) $[\ldots]<13>\mathrm{E}$ allora questo principe si è messo a camminare e cammina e cammina, è arrivato in un posto $[. .],.<14>$ Cammina cammina cammina ...continuò a camminare per un paio di mesi [...] E riprese il suo viaggio. Cammina cammina cammina, camminò ancora un paio di mesi in quella sterminata prateria.[...] Cammina cammina cammina ...camminò ancora un paio di mesi, sempre in mezzo a questa prateria [...], < 15> Egli si mette a girare attorno alla pianta, gira e gira, dieci, venti volte, e poi girò ancora finchè mancò poco allo scoccare della mezza-notte. [...] Anche lui girò, girò, continuò a girare attorno alla pianta, e girò ancora, finchè mancarono dieci minuti a mezzanotte, neppure tanto.[...], <16> [...] dopo un po' decise di partire e di andare a girare il mondo finché non avesse trovato una donna cosi. Gira e gira, non la incontrava mai.

ii) Accumulative epanadiplosis of action verbs. The (AE) of verbs of thoughts, statements and emotions intensifies their short, although vivid performance to the audience. In the examples $\langle 17-18\rangle$ it is noticed the emotional charge of the heroes through the accumulation of relative action verbs that intensify the magic power of the externalized actions $<19$ $20>$.

$<17>$ Caspita, la bambina era disperata $\underline{\text { e urlava, }} \underline{\text { e urlava }}, \underline{\text { e urlava }}[\ldots],<18>$ Poi cominciò a tremare a tremare, poveretta $[\ldots]<19>$ Allora il vecchio cresce, cresce, fino a che con la testa tocca le travi $[. .]<20>$. Allora il cane si è messo a leccarle e leccarle con la lingua, e le piaghe sono guarite.

Sometimes, the $(A E)$ of an action verb reveals the story-teller's habit of modernizing the folktale by the addition of personal experiences or of sociocultural data of his era. The introduction of new words or the replacement of older linguistic patterns achieves what Schmidt calls the «prop shift» (Lüthi 1987:69) <21>. Also, the (AE) of action verbs becomes the appropriate means of depicting scenes of violence and cruelty, since the "catharsis" of the audience stems from the punishment of the evil and the fair reward of the good (Meraklis 1986) <22>. Obviously, the combination of (AE) with the cohesive epanastrophe consists of a common topic with the motion verbs as well as with the action verbs <2325>.

$<21>$ Tre dei quattro amici fotografano e fotografano, che non so quante ne hanno fotografate, <22> Allora lui comincia a tagliare il collo, e via che taglia e taglia, e sega e sega, e ci mette più di una settimana per tagliare 'sto collo. <23> E il maestro partò e dopo poco scomparve alla vista di Rodolfo che si era seduto sulla spiaggia ad aspettare. E aspetta e aspetta e aspetta e aspetta, ma non vede arrivare nessuno. <24> Corse verso il cavolo e cominciò a tirare con tutta la forza. Tira che ti tira il cavolo non veniva via., $<25>$ Giovanni il cicoriaro cominciò a tirare. Tirava, tirava con tutte le forze ma la cicoriona non veniva via.

iii) Accumulative epanadiplosis of nouns. The coordinating conjunction of nouns expresses the accumulation either of the duration of the motion $\langle 26\rangle$ or of the duration of a state $\langle 27-28\rangle$. Also, it accentuates the distance that the hero must cross in order to reach his destination $\langle 29\rangle$, while its occurrence at the end of the tale provides to the audience optimism 
and hope during its abrupt transfer from the imaginary spacetime of the tale to the cruel world of reality $\langle 30\rangle$.

<26> Camminò a lungo, ore e ore. <27> Per consumare un paio di scarpe di ferro, cari miei, ci vogliono anni e anni, perché il ferro è duro! $<28>$ Per giorni e giorni non si sentì più cantare in riva al lago. $<29>$ Eppure ho fatto miglia $e$ $\underline{\text { miglia per venire da So-tutto... }<30>E \text { cosi vissero, tranquilli e contenti, per anni e anni. }}$

\subsection{The figure of emphatic epanadiplosis (EE)}

The (EE), as recurrence of linguistic and syntactic patterns, occurs, mainly, in the dialogic parts providing liveliness to the narration. The figure expresses the subjective state of the heroes serving the emotional function of the language, while it contributes to the entertainment of the audience (Nakas 1996b:231-2). Here, the intonation obtains a descendingaffirmative contour, the pitch of the story-teller's voice seems to swoop down in order to emphasize points of rhetorical importance: f.e. Tro $\left({ }^{2} / 3 \downarrow\right)$ tha $\mid$ tro $\left({ }^{2} / 3 \downarrow\right)$ tta $\mid$ tro $\left({ }^{2} / 3 \downarrow\right)$ tta $\mid$.

The (EE) occurs, mainly, in its continuous form /a a/ or /...a a .../ but it may, also, take a non continuous form as $/ \ldots \mathbf{\alpha} \mathbf{\alpha} \boldsymbol{\alpha} . . . /$ due to the interference of words that interrupt the fluidity of the patterns of the epanadiplosis. As regards the continuous epanadiplosis of an utterance, the figure emphasizes the voice of the heroes $\langle 1-2\rangle$. We can assume that psychological factors impose the use of the (EE) of an utterance to show intense motions as sorrow, desire, surprise, query, exhortations or orders $\langle 3-6\rangle$.

<1> E come arrivò lì sotto cominciò a fare: "A chi mi dà un bacio, gli do un chilo di pesce! $A$ chi mi dà un bacio, gli do un chilo di pesce!», <2> [...] poi andò in città con due pennelli nuovi, teneri, belli, cominciando a gridare: «Chi vuole indorare il culo e chi lo vuole inargentato? Chi vuole indorare il culo e chi lo vuole inargentato?» Figuratevi le donne che erano alle finestre! «Ma senti cosa dice quello là! Ma senti cosa dice!», <3> [...] le quattro donne si risvegliano e cercano non lo vedono cominciano a piangere e a gridare : «La muta ha mangiato il bambino! la muta ha mangiato il bambino !»,<4> «No, glielo dobbiamo portare, glielo dobbiamo portare» [...], $<5>$ Lucrezia corse fuori di casa mentre la madre la inseguiva gridando: «Tutte e sette in dieci minuti! Tutte e sette in dieci minuti!», <6> Come lo vide, lei esclamò: [...] Tornate giù subito! tornate giù subito!»

Also, the (EE) of an utterance functions as a standard verbal «formula» $\langle 7\rangle$ which generates magical outcomes and expresses the tension of the magical processes (Lüthi 1987:88). Often, the figure occurs in the context of a metrical system, common in use in the folktales for expressing linguistic patterns with universal character (Luthi 1987: 47) ${ }^{1}<8$ 12>.
$<7>$ Vai sulla montagna e con questa bacchetta devi dire: «'Coda di asino vienimi in fronte, coda di asino vienimi in fronte, coda di asino vienimi in fronte», $<8>[\ldots]$ ma la volpe le botte non le aveva prese e faceva: «É tintano è tintano e il rotto porta il sano. Ė tintano è tintano e il rotto porta il sano », $\langle 9\rangle$ E lungo la strada andava facendo: "E se me la manda buona Dio mai più feste in cielo io. $E$ se me la manda buona Dio mai più feste in cielo io», $<10>$ E lei sempre ripeteva: «Lendinelli, pidocchielli, come noi altri cristianelli. Lendinelli, pidocchielli, come noi altri cristianelli», <11> «Ucci, ucci, odor di cristianucci...», <12> «Fumaccio fumaccio, odor di cristianaccio; non m'inganno che ci sia, carne di cristiano in casa mia!»

The $(E E)$ in successive stages of the narration highlights the obstacles that the hero affronts during his/her itinerary, while its use makes more apparent special qualities of persons or objects of the folktale $<13-14>$ :

<13> "Porta ammazzala, porta ammazzala!" - diceva la cassetta.[...] Perina arrivò al fiume e la cassetta diceva: « Fiume affogala, fiume affogala!» [...] Arrivò dai cani e la cassetta : « Cani man-giatela, cani mangiatela!», <14> «Eे tanto bello, è tanto bello, però manca una cosa» [...]

b) The (EE) of verbs, adverbs and exclamations enhances the concept of the performance as a theater game (Genette et al. 1987:63). Furthermore, the (EE) of vocatives serves to the connative function of the language which focus the interlocuteur-hero or the magic object-recipient of the message of the folktale $<15-18\rangle$.

1 Lüthi (1987) presents analogous patterns of German, Greek and English folktales: "Ich rieche, rieche Menschenfleisch" (German), "Ou!

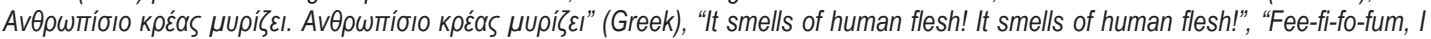
smell the blood of an Englishman". Lüthi, Max. 1987. The Fairytale - As Art Form and Portrait of Man, p. 47. 
$<15>\mathrm{E}$ tutte e sette si sganasciavano dalle risa: «Trotta, trotta trotta!» [...] «Trotta, trotta trotta!», <16> «Ah, bravo, bravo», gli rispose l' uccellino [...] $<17>$ «Figlia di fata, figlia di fata cala le tue trecce e fa salire tua madre!», $\langle 18>$ «Bastoncello, bastoncello, portami a rivedere la mia prima sorella» [...].

\subsection{The figure of gradable epanadiplosis (GE)}

In the folktale men, objects, actions, qualities lose their earthly qualities. They shrink at an extreme point or they expand, acquiring cosmic dimensions. In this way, the aesthetic result of hyperbole is achieved through the figure of (GE) of adjectives and adverbs (Nakas, 1996b). The appropriate intonation of the homo narrans consists of a necessary condition for the successful transmission of the figure. The repeated adjectives or adverbs consist of a single prosodic unit where the decline of the prosodic contour stresses only on one of the reiterated words : f.e. FOR( $\downarrow)$ t iforti. The (GE) intensificates the intended meanings corresponding to the superlative of the qualitative adjectives (Dardano 1995:218$20)<1-2\rangle$, while the graduation of the mentioned quality is intensified due to the use of diminuative or accretive nouns as attest the suffixes inolone $<3-4>$. Also, the figure facilitates the presentation of antithetical qualities of persons, animals, objects achieving the result that Lüthi calls «Gegenbilder» (opposite pictures) (Meraklis 1993:298) <5>.

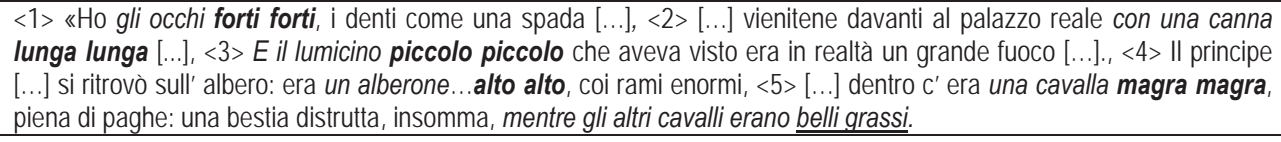

The (GE) of the spatial/locative adverb lontano (=far) intensifies the vagueness of the distance, extends the itineraries that the hero must cross and transfers the action to a zone which is inaccesible for the ordinary humans $<6-12\rangle$.

$<6>$ Finalmente una mattina scorse, ma Iontano Iontano, un altro castello che luccicava $[\ldots],<7>$ «Non posso fare
ritorno alla mia casa, che è Iontano Iontano, sulla Montagna dei Sette Vetri $[\ldots] »,<8>$ Sono arrivato in ritardo perché
ero all' albero dell' idolo del sole che è lontano lontano di qui $[\ldots],<9>$ Dalla casa del mago si vedeva, Iontano Iontano,
il paese della Nicolina $[\ldots],<10>$ Dopo un po' che girava però vide, lontano Iontano, un lumicino $[\ldots],<11>$ Finalmente
un giorno vide, Iontano Iontano, un grande palazzo che luccicava $[\ldots],<12>$ Baffi di Rame salì su un albero per vedere
se si scorgeva qualche casa e Iontano Iontano vide una luce.

\subsection{The figure of epanastrophe}

Epanastrophe is related to the presentation of a supplementary information relative to the semantic content of the nucleus (noun, adjective, verb, adverb) of an initial clause during its repetition in a second, adjacent clause. Epanastrophe is classified to the following categories (Nakas 2002a): I) Supplementary epanastrophe (SE). It is classified to the next sub-categories: i) (synthetic)-generative epanastrophe (s-gE) and ii) syntactic epanastrophe (sE) and II. Cohesive epanastrophe (CE).

i) The (s-gE) is achieved due to the supplementation of intensive prefixes as (stra-, $r(i)-, r(e)-$, sper-) to verbs $<1$ $8\rangle$, nouns $\langle 9\rangle$ or adjectives $\langle 10\rangle$ of the first clause, repeated in the second adjacent clause in order to show the element of hyperbole or to intensify the presented actions.

$<1>$ Stellina, poverina, piange e si dispera, prega e straprega [...] $<2>$ Pensa e ripensa, il contadino si ricordò che $[\ldots],<3>$ A casa la matrigna non fece che parlare di una bellissima ragazza che era apparsa in chiesa e di come il principe non smetesse di guardarla e riguardarla [...], <4> II babbo capovolse il paniere, guardò, riguardò [...], <5> Pensa e ripensa, poi si dice [...], <6> Sta riempiendo il boccale e sente bruciare la braciola, accorre con il cannello in mano, volta e rivolta la braciola [...], <7> La strega, dopo avere bussato e ribussato alla porta..., infilò la testa [...], $<8>$ Pietrolino giurò e spergiurò che non aveva mai detto niente $[\ldots],<9>$ «Morte, stramorte, lasciami sta notte $[\ldots]$, $<10>$ La vedova non lo dava a vedere, ma era contenta e stracontenta [...].

Also, the occurrence of the (s-gE) is based on the supplementation of accretive or diminutive suffixes as (-etto, -accio, ello(a), -ino, -uolo) to nouns as well as to adjectives and adverbs in order to express the sympathy as well as the irony of the story-teller towards persons, animals and objects. In other cases, the addition of suffixes serves to the creation of internal, homophone rhymes schemes in the folktale $\langle 11-16\rangle$. 
$<11>$ «Eh, abbiamo un carro, un carretto pieno di sacchi di fotografie», <12>[...]; non ci sono uccelli e uccellacci in grado di farmela, $<13\rangle$ [...] Teresina pensava ad aiutare il padre e farlo sedere per riposare e a togliergli dalle mani pacchi e pacchetti, <14> Fate fasce, pezze e pezzuole per il figlio del re [...], <15> «Rompiti, brocca e brocchettella, che la mora saracena s'è fatta bella!», $<16>$ «Albero alberello dammi il vestito bello. Albero alberino dammi il vestito fino»s.

Suffixes as -ino and -one <17-18> characterize the epanastrophe of adjectives, while the addition of the suffix issimo(a) to adjectives $<19-21>$ and adverbs $<22-4>$ attests the superlative qualities or virtues that characterize heroes and objects.

$<17>[\ldots]$ veramente ha trovato un piccino nato, un piccinino come diciamo noi all' usanza nostra $[\ldots],<18>[\ldots]$ il mio
papà goloso golosone mi mangiò tutto $[\ldots],<19>$ Là, una bella, anzi bellissima ragazza, stava sdraiata $[\ldots],<20>$ Ma
devi coglierne tanta, tantissima, perche ne serve $[\ldots],<21>[\ldots]$ e vede che c' è dentro una rana cosi grossa che sarà
stata più di mezzo quintale, una rana grossissima.., $<22>$ «Qui è bello, bellissimo, però vi manca qualcosa $[\ldots] »,<23>$
II fiume Giordano è lontano, lontanissimo $[\ldots]<24>$ E possibile, possibilissimo! Perché tu sei schemo come una
cucuzza $[\ldots]$.

ii) The (SE) is actualized due to the syntactic relation of the supplementary informative elements, given by nouns, adjectives, adverbs, prepositions, subordinate clauses, to the word which is repeated either by a coordinating or a subordinating conjunction. In the following examples the supplementary information is given by an adjective or more $<25$ $31>$.
$<25>$ Vicino alla casa del mercante abitava una vedova, una vedova povera [...], $<26>\mathrm{E}$ allora gli ha fatto vedere la lettera, la lettera falsificata, <27> «Cancello, cancello fatato », strillò l' Orco», <28> Poi se non riesce così, ci deve mandare una carrozza, una carrozza reale!, $\langle 29\rangle$ «Fichi, fichi maturi in gennaio, comprate i fichi!», <30> Poi andrai in fondo, dove ci sarà dentro della terra, della terra bagnata e sporca., <31> C' erano infatti le fate, sette fatine* impertinenti, figlie di un mago [...]. (*in combination with a (synthetic)-generative epanastrophe)

A stylistic device of the folktale is the isolation of adjectives that accentuate notions as beauty (Meraklis 1993:40,42-3; Lüthi 1982:33). The inclusion of such an adjective in the figure of the (SE) potrays the prementioned quality in a more vivid way $<32-34>$.

<32) Balena, mia bella balena dammi tanta catena [...], <33> Gli devi dire così che noi siamo tre sorelle, tre belle sorelle [...]», <34> «Bergamotta, bella Bergamotta! Butta giù le tue trecce per tirar su la tua cara madre!» [...] La madre ritornò alla sera e chiamò: «Bergamotta, bella Bergamotta! Butta giù le tue trecce...»

In other cases, the supplementary information is provided by an adverb $<35-41>$ which puts emphasis on the tension $\langle 42-3\rangle$ or on the relaxation in action $\langle 44\rangle$, while the occurrence of the adverb proprio (=really) affirms and emphasizes the meaning of the repeated linguistics patterns $\langle 45-6\rangle$.

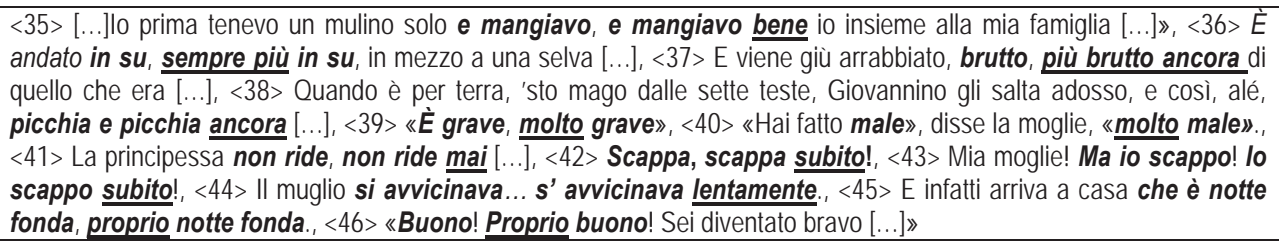

Also, a particular form of (SE) is realized. The adversative conjunction ma interferes among the successive reiterated patterns $\langle 47\rangle$. As a result, the implied notions are intensified due to the use of the word tanto (=so much) either as an indefinite adjective $\langle 48-52\rangle$ or as an adverb/complement of the adjective $\langle 53\rangle$, alternatively $\langle 54-56\rangle$ or in combination with the adverb cosi (=so) $<57>$. Furthermore, the use of prepositional phrases (with the prepositions $d a, i n, a \ldots)<58$ $65>$ specifies and clarifies the meaning of the repeated linguistic patterns of the (SE).

$<47>[$...]c' era un eremita vecchio, ma proprio vecchio., $<48>$ Infatti la vendette e col ricavato comprò tante uova ma tante uova $[. .],.<49>\mathrm{E}$ fa tanta strada, ma tanta strada che arriva $[. .],.<50>[. .$.$] e gli dà tante botte ma tante botte$ 
che lo manda a finire [...], <51 $>$...e non dubitate che cominciarono a fioccare tante bastonate ma tante bastonate che le monache cominciarono [...], <52> E ci hanno messo tanto tempo, ma tanto tempo che non so quanto [...], <53> Hanno rabbia perché siete tanto ma tanto belli, e non c'è nessuno bello come voi $[\ldots],<54>[\ldots]$ una volta un pescatore aveva sette figli, e poverino era cosi povero ma cosi povero!, $<55>$ E il bambino a scuola era cosi bravo, ma cosi bravo [...], $<56>[\ldots]$; si voltò e vide una donna cosi bella... ma cosi bella come non ne aveva mai visto [...], $<57>$ Ma sta a vedere, poverino, che è tanto sfortunato ma tanto sfortunato che, di pesci ne prende sempre cosi pochi ma cosi pochi che, sua moglie poveretta continuava a dire [...]

$<58>$ Fecero un pranzo di nozze, un pranzo di nozze a strangozzo $[\ldots],<59>[\ldots]$; era una donna povera, povera in canna [...], <60> Allora torna indietro, 'sto Gianchepicchia, e alè botte su botte, botte da orbi [...], <61 $>$ [...] e alla fine vede un' ombra, l'ombra di un uomo e pensa, <62> Ha fatto esporre tutti gli avvisi, fra una settimana ci sarebbe stato il torneo, il torneo delle figlie del re [...], <63> Cari miei, il Cicasa era là dentro, e comincia a cagare, a cagare della paura [...], <64>[...] «Cuoco, cuoco della mala cucina che fa il re con la mora Saracina?», <65> Sono favole, neh! Sono favole di una volta.

The (sE) provides supplementary information relative to the reiterated linguistic patterns by the use of: i) a noun $\langle 66-68\rangle$ or a noun phrase $\langle 69-71\rangle$, ii) a verb $\langle 72-74\rangle$, iii) an utterance $\langle 75\rangle$ or iv) a subordinate clause $\langle 76\rangle$. The relative clause introduced by subordinate conjunctions as che, come $<77-82>$ belongs either in the category of declarative relative clauses which define more precisely a term of the antecedent clause or the entire clause or in the category of relative clauses that contain the adverbial meaning of cause, consequence, purpose etc. Last, the figure of (sE) may be combined with the (s-gE) demonstrating the narrative skills of the story-teller $<83-84>$.

\begin{abstract}
$<66>[. .$.$] rimasta orfana viveva con una zia, una zia monaca [...], <67> C' è questo Giovannino senza paura-un$ poveretto, un povero contadino $[. .],.<68>\mathrm{E}$ c' è anche suo fratello, suo fratello Stellante $[\ldots],<69>$ Le contarono e videro che erano cento: cento mele d' oro., $<70>\mathrm{E}$ andato, ha preso l' acqua, un boccettino d' acqua [...], $<71>V i$

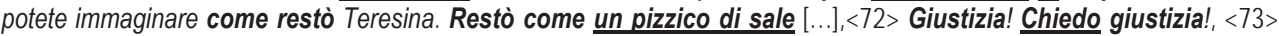
Belle sono belle, pensava [...], <74> Asilo? Domandi asilo?, <75> «Guarda che forse non ci vedremo più, in ogni modo», e l' aveva preso da parte, da sola, «in ogni modo ti do questo scatolino d' oro» [...], <76> «Ma io vi domando», insisteva lei, «vi domando se avete visto passare un ragazzo e una ragazza!, <77>«Ah, vedo, vedo che ce l' hai», <78> "Cosa credevi», rispose la ragazza, "credevi forse che fossi morta?», <79> Subito senti addosso un gran peso, un gran peso che lo soffocava ;[...], <80> «Ogni notte il drago, padrone di questo mondo, il drago che tu hai ucciso, ci trasformava in uccelli [...]», <81> «Venitemi ad aiutare, io vi ho fatto mangiare, venitemi ad aiutare che ora ho bisogno io», <82> "Comando comando che tutti i proiettili del re siano di stoppa e i miei siano tutti veri», <83> Quando è su, ancora più arrabbiato, arrabbiatissimo, arrabbiato come una bestia», <84> || mattino seguente il gatto era tutto bianco, un bel gattone tutto bianco: [...]
\end{abstract}

II. Cohesive epanastrophe (CE) (Nakas, 2002b). The (CE) is based on the repetition of the predicate or of a part of the predicate that functions as an informative nucleus after a strong punctuation mark. It guarantees the coherence of the narration. The figure is actualized either by: a) an asyndetic coordination or by b) a syndetic subordination.

a.Asyndetic coordination. This form of (CE) denotes, mainly, a temporal arrangement of events. The epanastrophe of an utterance presents the realisation of an action which is followed by another action(s) due to the conjunction $\mathbf{e}(=a n d)$ empowering the conception that one of the most preminent characteristics of the oral expression is rather the coordination than the subordination (Ong 2002: 37-38) $<1-8>$. Also, the figure becomes a helpful technique for the story-teller in order to regain his train of thought after a commentary or interpretive interference $\langle 9-12\rangle$.

$<1>$ Che andò a fare il servo dal re, andò a fare il servo dal re ed era sempre malinconico [...], <2> E la sorella se ne tornò a palazzo reale con il fratello, tornò con il fratello, il re appena la vide la cercò in moglie [...], <3> E allora fu arrestato, $\underline{f u}$ arrestato e fu portato davanti al re [...], <4> E intanto il re si nascose, si nascose e vide tutto [...], $<6>$ Allora il vecchio tornò a battere l' acqua con un altro colpo, guarda e non la vede arrivare. Tornò a battere l' acqua una terza volta [...], $<7>\mathrm{Ha}$ visto che ne aveva ammazzate tante e le ha contate: le ha contate, ed erano trecento!, $\langle 8>$ C' erano due comari che andavano sempre d' accordo fra loro, e una si chiamava comare Asinetta e l'altra comare Capretta. Andavano sempre d' accordo, e allora un giorno [...]

$\langle 9\rangle$ «lo, se fossi in lei, prima che venga a saperlo il re, andrei a tirar fuori di prigione quel tale», era un gran farabutto, che aveva non so quanti anni di galera da fare, un delinquente di prim' ordine «andrei a tirar fuori di prigione quel tale, porterei da lui i bambini [..]», <10> E lei la cercava i pidocchielli e allora la vecchia le domandava - questa vecchia era una maga - e allora le domandava[...], <11> Allora viene mattina- nelle favole le ore passano presto -; viene mattina e sono 

$[\ldots]$.

Sometimes, it is noticed a slight modification of the utterance that participates in the figure due to the occurrence of "substitutional patterns" $<13-15>$ as well as changes to the verb tenses $<16>$ and switches in modes $<17-24>$.

\begin{abstract}
$<13>$ Ora il principe ha davvero ubbidito allo scudiero, gli ha ubbidito e di nuovo il re non è riuscito a colpire ferocemente il principe [...], $<14>$ Lui gira il cavallo e lo mette sotto un ponte. Mette li il suo cavallo con su la cassa di marenghi d' oro [...], <15> Prima devi spianare quella montagna. La devi spianare in modo che si deve vedere il palazzo mio $[\ldots] .<16>[\ldots]$ hanno detto tanto, hanno fatto tanto, ma non c'è stato niente da fare-lei è partita. $E$ allora questa ragazza parte, saluta [...], $<17>E$ pensa pensa, pensarono di andare dal re [...], $\langle 18>$ II vecchio sali in camera a cercare. E cerca e rovescia libri, guarda uno e l' altro [...], <19> Si prepara da mangiare e mangia e beve [...], <20> Quando arrivano dove c' era la piastra da sollevare, la sollevano e vedono che [...], $<21>$ Gli altri due preparano da mangiare, mangiano, ma lui sta zitto zitto [...]., <22> [...] passò di là un capraio e trovò un osso e questo aveva la forma di un flauto e cominciò a suonare; e suonava e la musica diceva [...], <23> Potete immaginarvi la rabbia di Lisa, ma non la dava a vedere perché voleva essere invitata allo sposalizio. E infatti fu invitata., $<24>$ Poi tirarono a sorte per vedere a chi

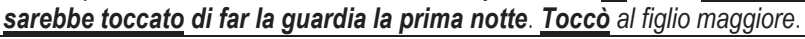

b. Syndetic subordination. Here, the epanastrophe reiterates a verbal pattern in the context of a secondary/dependent clause. Due to the use of a temporal conjunction, the semantic relationship of time is expressed between the two clauses. The conjun-ctions, most common in use are: quando (=when), mentre (= while), prima di (=before), come (= as), dopo che (=after), appena che (=as soon as) <1-5>.

\begin{abstract}
$<1>[. .$.$] e allora fa presto, arriva presto dai suoi genitori. Quando arriva è una sera scura [...], <2> Si coricò vicino alla$ nipote perché sorvegliava, mentre la sorvegliava stava a vedere [...], <3> Non appena arriva, il gallo canta, come il gallo canta, il portone si apre, <4> E allora lui apre la valigina, e come l' apre viene fuori una gran fiammata di fuoco [...], $<5>$ Sedette a tavola: mangiò e bevve, quindi si addormentò sulla tavola. Quando il mago fu ben addormentato e russava, la Bell' Aurora, in punta di piedi, uscì [...].
\end{abstract}

Changes in verb tenses or modes also occur. We notice switches as: a) from past continuous to simple past and from past simple to past continuous $\langle 6-11\rangle$. As regards the switches in modes, the most common are: a) from the present infinitive to the indicative mode (i) of past perfect, (ii) of future tense, (iii) of simple past, (iv) of present, v) of past continuous, b) from the (i) indicative of present or (ii) of simple past to present infinitive $<12-21>$.

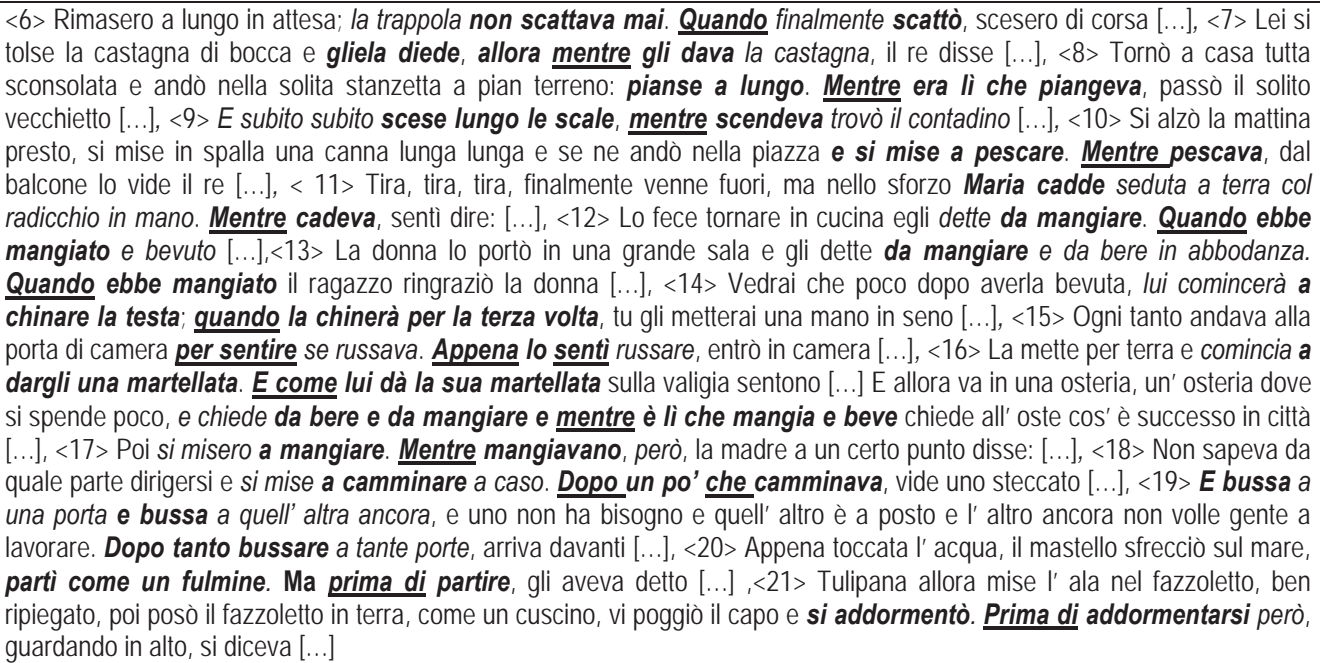

Also, the story-teller may create "cohesive complexes" due to the juxtaposition of successive (CE) - either by an asyndetic coordination $\langle 22-3\rangle$ or by a syndetic subordi-nation $\langle 24-5\rangle$ or in various combinations $\langle 26-27\rangle-$ in order to 
create a "chain" epanastrophe with scalar function' as regards the development of the plot (Nakas 2003:343-4).

\begin{abstract}
$<22>$ Così Cicasa va a comprarsi i sigari, e poi va in chiesa. Va in chiesa, chiude la porta, si siede in un banco, ..., e lì incomincia a fumare. Fuma un cigaro, ne fuma un altro e un altro ancora. Insomma li fuma tutti, $<23>$ II re - e che lui mancava il modo di trovare i sette figli maschi? - tanto fece che li trovò, diede loro una mazza l' uno e andarono a mare. Andarono a mare da Giovannuzza, Giovannuzza stava seduta sulla riva del mare e i fratelli maschi, tutti quanti, diedero un colpo l' uno con la mazza sopra le catene. $E$ spezzarono le catene. [...] E allora la Sirena si avvicinò, si avvicinò e le mandò la sorella. Le mandò la sorella, il re appena vide che aveva questa stella d' oro in fronte, disse $[\ldots],<24>$ II re era molto cagionevole di salute e ogni anno si ammalava piuttosto gravemente; mentre era a letto ammalato, ogni anno faceva un voto : prometteva che appena guarito, sarebbe andato a Roma a visitare i luoghi santi e a prender la benedizione dal Papa. Ma poi, quando era guarito, dimenticava il voto e si occupava del suo regno, <25> La madre lo fece restare a dormire in quella sera e lui disse che sarebbe partito il mattino dopo. Mentre il ragazzo dormiva, però, alla madre venne una gran voglia di baciarlo e lo baciò., <26>Ma lui, senza pensarci troppo, prende il badile e gli taglia il collo. Mentre taglia il collo a quello lì ne salta fuori un altro, poi un altro, poi un altro... Insomma, ne saltano fuori cinque e lui li ammazza tutti e cinque [...], <27> Allora prende la sciabola e le taglia la testa; come la taglia la testa, lui piglia e lecca...voleva leccare il sangue della ragazza perché era innamorato della ragazza... Lecca la spada e vede che era dolce e le dice : «Dolce in vita e dolce in morte».
\end{abstract}

\title{
3.5 The figure of epanaforá.
}

Epanaforá is related to the reiteration of "autonomous linguistic patterns" in the beginning of successive units of phrases, sentences, verses, stanzas or strophes with the necessary condition that grammatical parallelism exists among the above units (Nakas 2000:348). It is noticed, mainly, the epanaforá of: a) verbs/verb phrases and b) adjectives/numeral adjectives.

a.Epanaforá of verbs or verb phrases. The figure enhances the rhetorical dynamic of the folktale either by showing the characteristic of hyperbole or by emphasizing various acts which lead to the culmination of the action, mainly, during the third attempt according to the epic law of treble repetition. Also, the figure provides a dramatic vraisemblance, especially in the dialogic parts, while it excites the curiosity of the audience and makes the narration more fluide and pleasant $\langle 1-6\rangle$.

$<1>$ Questo re aveva dei grandi regni, aveva richezze senza fine, aveva soldati quanto la sabbia del mare, aveva palazzi e cavalla [...], <2> E la selvaggina era abbondante: prendeva lepri, prendeva fagiani, prendeva cinghiali..., $<3>$ Fatti in là, bastardino, fatti in là, bastardina!, <4> Siamo senza casa, siamo senza niente: [...]., <5> Non c'era nessuna casa, non c' era nessuna capanna, non vide alcun lume., $<6>$ Non sapeva cosa fare, non sapeva dove andare.

Sometimes, the epanaforá of verbs/verb phrases occurs in the context of a metrical system (Nagy 2004:139), adopted in all species of oral narrative (Meraklis 1999:99-102), according to the Homer's example (Thomas 1992) in order to offer a more poetic character to the narration (Skartsis 1994:80) $<6-7>$.

$<6\rangle$ «Venga dal monte, venga dal piano, sento qui dentro odor di cristiano». [...] Ma quello insisteva: «Venga dal monte, venga dal piano, sento qui dentro odor di cristiano», <7> Riluce la luna, riluce il sole ma quella che scivola ha più splendore.

Also, a particular occurrence of epanaforá of verbs/verb phrases is noticed (enumerative epanaforá). The repeated verbs/verb phrases in combination with cardinal (uno, due, tre...) $<11>$ or ordinal (primo, secondo, terzo...) $<8-11>$ numeral adjectives actualize a schematic form of enumeration. We assume that the laws of double and treble repetition lie beneath this stylistic and aesthetic structure. Especially, as regards the treble repetition, Lüthi (1987:44-5) ascribes to number three an important enumerative role, because of its symbolic position among the "individuality and the formless complexity".

$<8>$ Così, passa una sera, ne passano $\underline{\mathrm{due}}$, ne passano tre, e sempre la stessa storia., <9> Piangendo e lamentandosi aspettò il primo giorno e l' uomo non venne; aspettò il secondo, ma arrivò la notte [...], <10> C'era una donna con una figlia grande e grossa e tanto mangiona che quando sua madre portava a tavola il minestrone lei ne mangiava un piatto, ne mangiava un secondo, ne mangiava un terzo $[. ..] .,<11>$ Passa un canarino, ne passano due, ne passano tre e non riesce a prenderne neanche uno. Ne passano cinque, ne passano sei, ne passano sette e gli scappano tutti. 
Often, the treble enumerative epanaforá of the verb passare (=to pass) denotes the undefined duration of a hero's immobility $\langle 12-3\rangle$ or becomes the stylistic and aesthetic device of 'relaxation' in the folktale. The temporal interval of inertia seems to help the hero to reach his maturity in the continuum of his adventures $<14-17\rangle$.

$<12>$ Passa un giorno, ne passa un altro, passano tre giorni e Giovanni non fa niente., <13> Passa un giorno, ne passano $\underline{\text { due }}$, e tre, ma Giovannino non lavora mai; [...], <14> Passa un mese, ne passano due, quando Motio si mette in testa di sposarsi., <15> Passa un giorno, ne passano due e lui si ristabilisce un po' [...], <16> Intanto passa una notte, ne passano due e la mattina arriva la vecchia strega $[\ldots],<17>$ Passa un po' di tempo, passa una settimana, e il re dice: [...]

Also, the enumerative epanaforá of verbs/verb phrases conveys the rythmic repetition or accumulation of an action until its completion, as reveals the use of temporal conjunctions as finchè, fino a che (=until) in the examples $<18-22>$. Moreover, the figure emphasizes the shift from internal to external dynamics by materializing disembodied situations as the hero's sentiments (Meraklis 1993: 155).

$<18>$ Allora, pianin pianino, fa uno scalino, fa due scalini, tre scalini, fino a che si porta vicino a Giovanni. <19> E allora quello lo chiama una volta, lo chiama due, lo chiama tre, finchè il re scende [...], <20> Cosi cambia la guardia, ne mette due, ne mette tre e non vedevano nessuno [...], <21> «Proviamo ad aprire le bocche a quelle sette teste, e vediamo se hanno dentro le lingue!» Ne aprono una, ne aprono due e le lingue non ci sono., <22> Però si siede, fuma un toscano, ne fuma due, ne fuma tre, passa da un banco all' altro senza pace.

Another particular occurrence of the figure is realized when the epanaforá of verbs/verb phrases is followed by antithetical pairs of words that express either spatial oppositions as di quà/di là (=here/there), da una parte/dall' altra (=on one side/on the other side) $<23-37>$ or temporal oppositions as oggi /domani (=today/tomorrow) <38-43>. The above combinations conveys more clearly the continuity of the motion or the duration of an action. Often, the figure emphasizes the fruitless efforts of the heroes as it is attested by the negation non $<32-37\rangle$.

$<23>$ Allora gira di qua, gira di là: [...], <24> Lui scappa di quà, scappa di là, vede una casetta senza porta [...], <25> Domanda di quà, domanda di là e gli dicono[...], <26> Sdirupa di qua, sdirupa di là, mi salvai la vita [...], <27> Lui lavorava da una parte, lei lavorava dall' altra e si sono costruiti un piccolo albergo[...], <28> [...] e passa da una parte e passa dell' altra e non arriva mai [...], <29> E allora cerca di mettere a posto la tendina, la tira da una parte, la tira dall' altra finché sente [...], <30> Gira da una parte, gira dall' altra, ogni tanto andava a ispezionare [...], <31> Viagqia di quà, viaggia di là, aveva visitato tutti $i$ suoi Stati [...], <32> Cerca di quà cerca di là, nelle stanze non c'era nessuno, $<33>$ Cerca di quà, cerca di là, ma non la trova [...], <34> [...]scivola di qua, scivola di là, a mezzanotte non erano ancora arrivati[...], <35> Quei poveri folletti, corri di quà, corri di là, la sera erano stanchi morti e non contentavano nessuno, $<36>$ E cerca di quà, cerca di là, non ci sono piü., $<37>C^{\prime}$ ' era una volta un re, che aveva perduto un anello di gran prezzo. Cerca di quà, cerca di là, non si trova.

$<38>$ Sentilo oggi, sentilo domani, il dio Giove si mosse [...], <39> E, passando oggi, passando domani, disse alla fanciulla di tanto in tanto dolci parole [...], <40> Mangia oggi, mangia domani, le Fate, passeggiando nel giardino, cominciarono ad accorgersi che il prezzemolo [...], <41> Dillo oggi, dillo domani, il padre per aver pace, vendette il cavallo [...], <42> Gratta e lamenta oggi, gratta e lamenta domani, i contadini decisero che [...], <43> Picchia oggi picchia domani, diventerà brutta.

Sometimes, epanaforá may be combined with the epiforá of another verb phrase creating the figure called symploki (in

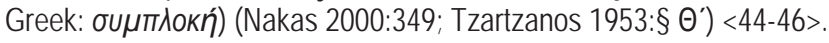

$\left\langle 44>[. .\right.$.$] chiedono da una parte, \mathrm{m}$ a $\mathrm{n}$ o $\mathrm{n} \mathrm{c}^{\prime}$ è $\mathrm{p}$ o $\mathrm{s} \mathrm{t} \mathrm{o}$; chiedono da un' altra, $\mathrm{m}$ a $\mathrm{n}$ o $\mathrm{n}$ c' è $\mathrm{p}$ o $\mathrm{s} \mathrm{t}$ o $[\ldots],<45>$ Guardò nel mare e n o n c' e r a, guardò nel cielo e $\mathrm{n}$ o n c' e r a, guardò sotto terra e lo vide [...], <46> Passò dall' albero di melo e n o n I i t r o v ò, passò dall' albero di pesco e n o n I i t r o v ò, passò dall' albero di pero e c' era la vecchiettina [...].

b) Epanaforá of adjectives/numeral adjectives. Also, epanaforá is realized mainly, by the repetition of numeral, cardinal adjectives $\langle 1-5\rangle$. Besides the essential role of numbers as cosmic symbols (Benoist:1992), their repetition in the folktale: i) accentuates the agonizing effort of the hero to reach his goal, ii) enhances the element of hyperbole, iii) emphasizes the role of the 'gift', which develops the action through the occurrence of dynamic relations (Meraklis 
1993:296-7) and iv) finalizes the execution of certain crucial events.

$<1>$ Per trovarti ho consumato sette paia di scarpe d i f e r r o, sette mantelli d i f e r r o, sette cappelli d i f e r r o;, <2> Ci sono dentro cento lenzuola, cento asciugamani, cento tovaglie, cento camicelle ricamate, cento camicie da notte, insomma cento di tutto[...], <3> Poi del mio sangue ne darai tre gocce alla tua moglie e ti farà dono di tre bei bambini; tre gocce le darai alla tua cavalla e questa ti farà dono di tre bei poledri; e poi tre gocce le darai alla tua cagna e $\underline{t} \underline{i}$ farà dono di tre bei cani..., <4> E infatti, cari miei, in quella festa hanno annunciato il loro fidanzamento: «...e fra un anno, un mese e un giorno ci sposiamo». [...] così sono passati un anno, un mese e un giorno e quel ragazzo l' hanno vestito come un principe., <5> Dopo un anno un mese e un giorno-nelle favole fa presto a passare il tempo [...]

\subsection{The figure of epiforá.}

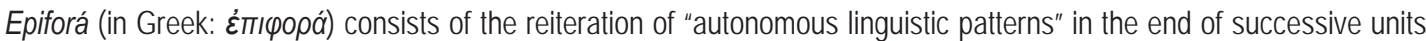
of phrases, sentences etc. and consists of "one form of parallelism which uses the repetition to bring the metrical and syntactic frames into alignment" (Nakas 2000:348). The figure results in brighting up the narration by rendering the given informations more persistently and emphatically $\langle 1-4\rangle$. Often, epiforá is related to the reiteration of words-signs of metallic or mineral products. The gold, the crystal or the gypsum become symbols of maximal qualities such as the extreme fragility, the inestimable value, the excessive effort, that is characteristic elements of the folktale's hyperbole $<5$ 9>. Rarely, can the figure appear in its synthetic form (synthetic epiforá) due to the reiteration of a bound and a free (or unbound) morpheme such as buontempo and tempo $<10>$.

$<1>$ «ll bestiame crepa di sete, tutti crepiamo di setel», <2> «Mamma», disse, «guarda che la ragazza si è arrabbiata. Avessi visto come si è arrabbiata!», <3> «No, il ponte non va bene, la carozza non va bene e il vestito non va bene», $<4>$ «Signor Gigante, io faccio il chitarraio, mio padre è chitarraio. Mio nonno è chitarraio, e tutto il mio parentado è chitarraio», $\langle 5\rangle$ «Perché sono fatto di malta, io sono un uomo di malta, se vado mi rompo, se torno mi spacco.», $\langle 6\rangle$ Sono fiori di cristallo, colti nel giardino di cristallo del mio castello tutto di cristallo., $<7>$ «Per trovarti ho consumato sette paia di scarpe di fero, sette mantelli di ferro, sette cappelli di ferro; [...]», <8> Però se volete che diventi la più bella villa del mondo, dovete piantare in giardino il melo dai frutti d' oro, la pianta che fa le mele d' oro», $<9>$ Va' dal tuo padrone e chiedigli una coppa di cristallo senza bolle, una gabbia tutta d' oro, staggi d' oro, gretole d' oro e beverello d' oro [...], $<10>$ E hanno avuto buontempo per tanto tempo.

\subsection{The figure of tautology.}

Tautology is the repetition of the same linguistic patterns $\left(x=x^{v}\right)$. In this case, the predicate doesn't offer additive information related to the subject (Nakas 2005:76; Nakas 1998:38). In the performance, tautology doesn't consist of a linguistic vitium, since pleonasm consists of a common oral narrative technique which advantages the story-teller to organize its narration (Ong 2002:40). Moreover, tautology enhances the particular grammar of the folktale. It emphasizes the definite and inescapable results of certain actions provoking major and spirited responses from the audience, while it offers the chance to the story-teller to dwell upon characteristics as the extraordinary and the absolute and to excite the imagination of the audience by playing a semantic game between the declarative and connotative content of the reiterated words $\langle 1-11\rangle$. It is worth mentioning that tautology may, also, be expressed by the figure ek parallilou (in

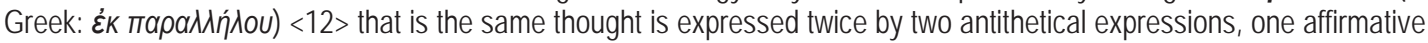
and one apophatic.

$<1>$ Tanto oggi c'e domani non c'è più, e chi s' è visto $\boldsymbol{s}^{\prime}$ è visto!, <2> Se ce la facciamo bene, sennò quel che sarà sarà., $<3>$ Quel che è stato è stato..., <4> Venite a desinare a casa mia, facciamo la pace e chi ne ha avuto ne ha avuto..., <5> II Re ci rest'o di pezza a vedere com' era stato svelto il gobbo; e, senza fiatare, perché parola di Re è parola di Re, chiamò [...], <6> Gli ordini sono ordini, hai capito? [...], <7> «La pelle è pelle», replicò l' orsa [...], <8> Nel tempo in cui il lago era ancora un lago, un contadino passava [...], <9> «Ma, da che mondo è mondo, le strade sono sempre appartenute ai malfattori [...]», <10> Bello è bello, non si può dir di no[...], <11> Caspita, gli uomini non sono più uomini. $[\ldots],<12>\mathrm{Ma}$, caspita, la muta è muta, e non parla. [...] Impiccavano la muta, che era muta e non poteva parlare.

\section{Conclusions}

To conclude, the stylistic analysis showed an extended use of figures of repetition in the performance of the Italian 
folktale. The prementioned conclusion empowers the assumption that figures consist of basic elements of the "internal structure" of the folktale genre (Günthner and Knoblauch 1995:11) that guarantee its stylistic and aesthetic features.

First, we noticed that the figures were used as essential expressive means, in various combinations, throughout the performance in order to realize stylistic features of the European folk-form: a) one-dimensionality, b) depthlessness and c) abstraction (Lüthi 1982). For example, the use of the accumulative epanadiplosis (AE) of the verb camminare (=to walk) or the gradable epanadiplosis (GE) of the spatial/locative adverb lontano (=far) succeeded to transfer the heroes as well as the audience to the supernatural world of the folktale and to accentuate the notion of 'otherness' through the implied geographical displacement. Also, the emphatic epanadiplosis (EE) was seen either as a means of the depthless representation of sentiments expressed in actions or as an expressive 'vehicle' of magical formulas, while the use of the supplementary epanastrophe (SE) achieved the clear but short presentation of heroes, objects, qualities in the folktale. Furthermore, figures as the gradable epanadiplosis (GE), epanaforá and tautology achieved the abstract folk-style either by isolating actions, heroes, objects, gifts or by revealing the "rare, the precious, the extreme" in the folktale (Lüthi 1982:38).

Second, the figures of repetition were revealed as a useful strategy for structuring the plot of the folktale. For example, the figure of the cohesive epanastrophe (CE) provided the story-teller with the necessary time to organise his thoughts and to prepare the narrative thread that he would follow, while it facilitated the perception of the plot by the audience during the performance.

From a comparative point of view, the findings of the dialectic relationship of the 'law' of repetition in the Italian folktale with the relative figures may enhance our knowledge about the 'universal' linguistic and stylistic patterns used in the folk-literature. The figures used in the Italian folktale present similarities to analogous linguistic and stylistic patterns (f.e. accumulative epanadiplosis, epanastrophe) in Balkan and Slavic folktales (Asenova, 1984:246; Nakas, 1996: 474-5). We can, also, refer to the particular use of the enumerative epanaforá that occurs, also, in the Greek folktale (Egglezou, 2004) or to the existence of similar figures of repetition in the African folk-literature (Finnegan 1992). Future stylistic studies of the folktale may reveal further analogies in its performance world-widely.

Despite the possible questions and limitations that arise in the ethnographic approach, relatives to the authenticity of the tanscribed speech of the examined Italian folktales (Papachristophorou, 2005), it can be supported that due to the above figures the formation of an artistic folktale's grammar coupled with the analogous rhetorical dynamic was realized. The figures of repetition became the creative tools which sharpened the magical, folktale style, intensificated the intended meanings and developped the necessary passion required for the successful conveyance of the Italian folktale to the audience during its performance.

\section{References}

Asenova, P. (1984). Fonctions de la repetition des mots en bulgare et en grec. Balkan Studies, 25(2), $243-61$.

Bakhtin, Mikhail M. (1976/1986). The problem of speech genres. In C. Emerson and M. Holquist (Eds.), Speech genres and other essays, (pp. 60-102). Austin: University of Texas Press.

Bauman, R. \& Briggs, Ch. L. (1990). Poetics and performance as critical perspectives on language and social life. Annual Review of Anthropology, 19, 59-88.

Beduschi, L. (scelte da) \& Cucchi, M. (tradotte da). (1986). Fiabe Lombarde. Milano: Arnoldo Mondadori Editore.

Ben-Amos, D. \& Goldstein, K.S. (1975). Performance and communication. The Hague: Mouton Press.

Benoist, L. (1975). Signes, symboles et mythes. Paris: Presses Universitaires de France.

Berry, J. (1991). West African folktales. Evanston, Illinois: Northwestern University Press.

Calvino, I. (2002). Fiabe Italiane (Vols. A', B', C'). Milano: Oscar Mondadori.

Chua, W. F. (1986). Radical developments in accounting thought. The Accounting Review, LXI(4), 601-632.

Dardano, M. \& Trifone, P. (1995). Grammatica Italiana con nozioni di linguistica. Bologna: Zanichelli.

Dawkins, R. M. (1942-3). The art of story telling in the Dodecanese. Byzantion 16(2).

Egglezou, F. (2004). Linguistic and stylistic patterns of the Italian folktale: A comparative research between the Italian and the Greek folktale. Unpublished Master Thesis. University of Athens: Faculty of Pedagogical Studies, Department of Language Arts.

Fettermann, D. M. (1998). Ethnography: Step by Step. Applied Social Research Methods Service, Vol. 17. London: Sage Publications.

Fialová, Chr. (2011). The dissociation of a change of location and the manner of its execution. Unpublished Master's Diploma Thesis. Masaryk University: Department of English and American Studies.

Finnegan, R. H. (1992). Oral traditions and the verbal arts: A guide to research practices. London: Routledge.

Gatto Trocchi, C. (a cura di). (2003). Le più belle fiabe popolari Italiane. Roma: Newton \& Compton Editori.

Genette, G., Marin L. \& Mathieu-Colas, M. (1987). The frontiers of narratology. Translated in Greek by Helena Theodoropoulou. Athens: Kardamitsas.

Gläser, R.. (1986). A plea for phrase-stylistics. In D. Kostovsky \& A. Szwedek (Eds.), Linguistic across historical and geographical 
boundaries, (pp. 41-52). Berlin: Mouton de Gruyter.

Gray, B. (1971). Repetition in oral literature. The Journal of the American Folklore, 84(333), 289-303.

Green, Th. A. (1997). Rhetorical analysis. In Th. A. Green (ed.), Folklore: An encyclopedia of beliefs, customs, tales music and art, Vol. 1, (pp. 725-727). Santa Barbara, California:ABC-CLIO, Inc.

Guiraud, P. (1975). La stylistique. Paris : Presses Universitaires de France.

Günthner, S. \& Knoblauch, H. (1995). Culturally patterned speaking practices: The analysis of communicative genre. Pragmatics, 5(1), 1-32.

Hymes, D. (1974). Foundations in sociolinguistics : An ethnographic approach. Cinnaminson, N.J. : University of Pennsylvania Press. Jakobson, Roman. 1966. Selected writings: Slavic epic studies (ed. Stephen Rudy). The Hague, Paris: Mouton.

Kudrnáčová, N. (2008). Directed motion at the syntax-semantics interface. Brno: Masaryk University.

Leech, G. N. \& Short, M. (1981/ 2007). Style in fiction: A linguistic introduction to English fictional prose. London: Longman.

Lüthi, M. (1982). The European folktale: Form and nature. Bloomington: Indiana University Press.

Lüthi, M. (1987). The fairytale as art form and portrait of a man. Bloomington: Indiana University Press.

Meraklis, M. (1986). The folktale and its pedagogical content. Itineraries, 2, 88-90.

Meraklis, M. (1988). The aesthetic of the folktale. Review of the Literature for Children, 3, 20-32.

Meraklis, M. (1993). Artistic folk speech. Athens: Kardamitsas.

Meraklis, M. (1999). The folktale-texts about the study of folktale. Athens: Hellinika Grammata.

Nagy, Gr. (2004). Poetics of repetition in Homer. In D. Yatromanolakis and P. Roilos (Eds.), Greek ritual poetics. Hellenic Studies 3 , (pp. 139-148). MA: Cambridge.

Nakas, Th. (1996a). Accumulative repetition/epanadiplosis. In Studies in Greek linguistics/ Proceedings of the $16^{\text {th }}$ annual meeting of the Department of Linguistics Faculty of Philosophy, (pp. 470-481). Aristotle University of Thessaloniki (4-6 May 1995). Thessaloniki.

Nakas, Th. (1996b). Lexical and phrasal repetition/epanadiplosis (Part A). Off-print from the Lexicographical Bulletin (Academy of Athens), Vol. K., (pp. 221-330). Athens:Academy of Athens.

Nakas, Th. (1998). Tautology and tautological reduplication. In Studies in Greek linguistics/ Proceedings of the $18^{\text {th }}$ annual meeting of the Department of Linguistics Faculty of Philosophy, (pp. 338-352). Aristotle University of Thessaloniki (2-4 May 1997). Thessaloniki.

Nakas, Th. (2000). Epanaforá, epiforá, epanodos. In Studies in Greek linguistics: Proceedings of the $20^{\text {th }}$ annual meeting of the Department of Linguistics. Faculty of Philosophy, (pp. 348-359). Aristotle University of Thessaloniki, (23-25 April 1999). Thessaloniki.

Nakas, Th. (2002a). Epanastrophe: The sub-case of the (synthetic)-generative epanastrophe. In Studies in Greek linguistics: Proceedings of the $22^{\text {nd }}$ annual meeting of the Department of Linguistics Faculty of Philosophy, (pp. 472-483). Aristotle University of Thessaloniki, (27-29 April 2001). Thessaloniki.

Nakas, Th. (2002b). Linguistic and paralinguistic patterns of the folktale's performance. In Thiteia: A Tribute to the Professor M. G. Merakli, (pp. 457-493). Athens: University of Athens and University of Ioannina.

Nakas, Th. (2003). Glossofilologika, Vol. D': Studies on language and literature. Athens: Eptalofos.

Nakas, Th. (2005). Figures of (morpho)linguistic and phrastic repetition, Vol. A. Athens: Patakis.

Niedermüller, P. (1978). Folk narrative research. Neohelicon, 6(1), 299-304.

Olrik, A. (1992). Principles for oral narrative research. Bloomington: Indiana University Press.

Ong, W. J. (2002). Orality and literacy: The technologizing of the word. London: Routledge.

Papachristophorou, M. (2005). Orality, transcription and construction of data. Indian Folktale, 4(1), 12-15.

Propp, Vl. Y. (1984). Theory and history of folklore. Minnesota: University of Minnesota.

Propp, VI. Y. (2012). The Russian folktale. Detroit, Michigan: Wayne State University Press.

Skartsis, S. (1994). Introduction to the folk literature. Athens: Hellinika Grammata.

Thomas, R. (1992). Literacy and orality in ancient Greece. New York: Cambridge University Press.

Tzartzanos, A. (1953). Neo-Hellenic syntax (of the common dimotiki), Vol. B'. Athens: OESB.

Volosinov, V.N. (1929/1986). Marxism and the philosophy of language. Cambridge, Mass.: Harvard University Press.

Wilson, St. (1983). The use of ethnographic techniques in educational research. In ERM 881 Case Study Methods 5 Readings 27-33, Perspectives on case study 4: Ethnography, 23-56. Melbourne: Deakin University. 
